RUNNING HEAD: Relationships, Affect and Health

\title{
Relationships and Health: The Critical Role of Affective Science
}

\author{
David A. Sbarra \\ University of Arizona \\ James A. Coan \\ University of Virginia \\ In Press, Emotion Review
}

Words: 8,962

Tables: 1

Figures: 2

Author note: Correspondence regarding this paper can be addressed to either David Sbarra (sbarra@email.arizona.edu) or Jim Coan (jcoan@virginia.edu). Portions of this paper were commissioned by the National Institute on Aging as a White Paper. The authors have no competing interests to declare. The first author's work on this paper was supported in part by grants from the National Institute on Aging (AG\#036895 and AG\#028454) and the National Institute of Child Health \& Human Development (HD\#069498). The second author's work on this paper was supported in part by a grant from National Institute of Mental Health (MH\#080725) and a grant from the National Science Foundation (BCS1261499). 


\begin{abstract}
High-quality social relationships predict a range of positive health outcomes, but no broadly accepted theory can explain the mechanisms of action in this area. The central argument of this paper is that affective science can provide keys for integrating the diverse array of theoretical models concerning relationships and health. From nine prominent theories, we cull four components of relational affect that link social resources to healthrelated outcomes. This component model holds promise for integrating research from the different theoretical perspectives and for generating new, mechanistic questions about connection between relationships and health. The paper closes by outlining three empirical study ideas that illustrate ways in which the different components can be studied together in the context of mechanism-focused research.
\end{abstract}

Keywords: Relationships; affect; health; emotion; relationship dynamics. 


\section{Relationships and Health: The Critical Role of Affective Science}

In May 2004, Phillip and Tom, both in their early forties, decided they would be among the first same-sex couples to marry in Massachusetts. The men had been together for over a decade and both considered their relationship to be of the highest quality, one in which they supported each other in effective ways, were intimate, caring, and responsive, and in which they enjoyed a committed sex life together. For both men, most aspects of life seemed easiest and most enjoyable when they were together. In 2005, just a year after they were married, Phillip noticed a lump in his left testicle and was quickly diagnosed with Stage III cancer. His testicle surgically removed, Philip continued receiving adjuvant chemotherapy with a good but far from certain prognosis.

The cancer diagnosis and its treatment was a major source of stress on their relationship. Phillip, a successful freelance graphic designer, was losing business quickly because he could not keep up with work demands. This pressure seeped into the relationship, too, as he became resentful of Tom's workhour flexibility-and even Tom's ability to do work at all. As Phillip struggled to avoid all cancer-related thoughts and feelings, Tom felt the distance between them grow. He no longer knew how to give Phillip the support he needed; he felt lonely and constantly vigilant about Phillip's needs. Moreover, Tom started to think he could no longer handle Phillip's rage; they fought, often and with vitriol, and both men would frequently lay awake at night (in an activated state of autonomic arousal) thinking about the destructive and hapless course of their new marriage. The more they fought, the less physical and emotional strength Philip had to battle his cancer. For both men, it began to seem as if the world was becoming a more demanding and intractable place, making even small tasks feel exhausting. 
Phillip and Tom are a fictional couple, but for the purposes of this paper, their story highlights many important themes. First, human health manifests in a relational context. As Phillip and Tom struggle to live with Phillip's diagnosis and treatment, their relationship difficulties make coping with the cancer even more taxing. Their story is consistent with a large literature on relationships and health. The evidence is unequivocal: High-quality, low conflict relationships are associated with better health, and this conclusion holds in both healthy and medically-involved samples (e.g., Holt-Lunstad, Smith, \& Layton, 2010; Idler, Boulifard, Contrada, 2012). The corpus of data in this area is informed by many different theories, each with their own perspective on how relationships may shape health and/or health-relevant outcomes. The question of how is essentially a question of mechanisms: What behaviors can best explain the connection between relationship quality and health?

Answers to this question are emerging but far from clear (cf., Robles, Slatcher, Trombello, \& McGinn, 2014). The primary purpose of this paper is to introduce new avenues for mechanistic research while also emphasizing integrative themes from the different theories on relationships and health. The story of Phillip and Tom provides a nice illustration of where to look for these new ideas and integrative themes.

First, for Phillip and Tom, as for all relationships, affect plays a leading role. Prior to the cancer diagnosis, their most blissful and easiest moments were together, and the emotional temperature of their relationship was quite positive. After the cancer diagnosis, Phillip raged and became plagued with anxieties. Tom retreated out of uncertainty and became mired in his loneliness. When they fought, they were both left feeling highly distressed-subjectively and physiologically. The world started to look different to them, more difficult, less accommodating. When thinking about the outcome of Phillip's cancer 
and the relational context in which it exists, the important role of these affective experiences, including both immediate and brief emotional responses (e.g., anger during a fight), as well as longer-term mood states (e.g. loneliness and disaffection), is unmistakable. In short, affective experiences both shape and are shaped by close relationships (see Shoebi \& Randall, 2015), and both of these processes are central to health (Kubzansky, Winning, \& Kawachi, 2014).

In the remainder of this paper, we attempt to integrate the study of affect and health into the study of relationships and health. This "bridge building" effort is organized in four main sections, the goal being to outline a series of new avenues and integrative themes for advancing the mechanistic study of relationships and health-specifically, how affect can explain why positive relationships are salubrious and negative ones are unhealthy. We begin with a brief and selective review of the research on affect and health. Given that the larger focus of this special section is on emotions and health, our goal is relatively circumspect and to introduce a mediational model for understanding the key role of affect in the relationship-health connection. Second, we discuss and briefly review major theories in the area of relationships and health. In this section, our goal is to survey the theoretical landscape in order to identify the cross-cutting principles, or the components, that may ultimately improve our understanding of how relationships are connected to health. The third section of the paper enumerates these components, which we believe are deeply embedded in contemporary affective science and, when placed in focus, have tremendous potential for advancing the study of relationships and health. Finally, we outline three empirical study ideas that illustrate the many ways in which the different components can be examined together in the context of mechanism-focused research. 


\section{The Study of Relationships and Health is the Study of Affect and Health}

Affect is an umbrella term for a range of emotional phenomena (Scherer, 1984), from the experience of pleasant or unpleasant feelings to the goal-oriented physiological and cognitive changes associated with specific emotional concepts, all of which can include longer-term mood states (Barrett, 2014). Across the terrain of affective science, several key ideas are relevant to the present review. First, emotional states provide rapid, vital and often implicit information about the world that guides perception, action preparation, and behavior (e.g., Beckes \& Coan, 2011; Clore \& Ortony, 2000; Schwarz \& Clore, 1983), and these actions often have a social function (Morris \& Keltner, 2000). In this way, affective experiences are an important source information (Clore, Gasper, Garvin, 2001), and emotion drives behavior and mobilizes resources to meet adaptive challenges (Frijda, 1986). Second, it is increasingly recognized that affect regulation - that is, the diverse set of behaviors that people engage in to influence their emotional experiences (see Westen, 1994) - occurs most often in a social context (Gross, Richards, \& John, 2006) and is itself an inherently social process (Campos, Walle, Dahl, \& Main, 2011; Coan \& Maresh, 2014; Levenson, Haase, Bloch, Holley, \& Seider, 2013; Niven, Totterdel, Holman, 2009; Parkinson, Fischer, \& Manstead, 2004; Reeck, Ames, \& Ochsner, 2016; Rime, 2007). Indeed, socially situated emotion regulation dynamics are observable in dyads from the cradle to the grade (Bowlby, 1969/1980; Mikulincer \& Shaver, 2005; Levenson et al., 2013).

The literature on affect and health is voluminous, with robust connections between both negative and positive emotions and a variety of health outcomes (see Chida \& Steptoe, 2008; Cohen \& Pressman, 2006; Cohen \& Rodriquez, 1995; DeSteno, Gross, \& Kuzansky, 2013; Hernandez et al., 2017; Kiecolt-Glaser, McGuire, Robles, \& Glaser, 2002; Kubzansky et 
al., 2014; Kubzansky, Cole, Kawachi, Vokanas, \& Sparrow, 2006; Suls, 2017). The broadbased effects observed in the literature likely unfold across several different physiological pathways, ranging from the direct alteration of autonomic, endocrine, and immune signaling in the face of negative emotion or stress (see Kiecolt-Glaster et al., 2002; Miller, Chen, \& Cole, 2009) to more indirect routes through health behaviors (e.g. Sbarra, 2016), which, when impaired, can alter the physiological processes that are relevant to disease incidence and progression. In a recent review, DeSteno, Gross, and Kubzansky (2013) argued that research on affect and health should move beyond the concept of stress and toward the study of specific emotions and emotion regulation. These authors also argued for an expanded study of interpersonal processes in the arena of affect and health, and this perspective is consistent with recent calls for investigators to "put emotions in a social context" when studying the connection between affect and health (see Kubzansky et al., 2014)

What is the social regulation of affect? In order to understand the association between relationships and health, we need first to outline our basic perspective on how relationships shape affective responses. Several eviews suggest that interpersonal emotion regulation is essentially self-regulation in an dyadic context, and this process of interpersonal emotion regulation necessarily involves the dynamic process of inferring others' psychological states then mobilizing resources for action and, potentially, empathic sharing (e.g., Reeck et al., 2016). From this perspective, one reason that social support buffers stress, for example, is that relational partners help us to reappraise potentially negative events (see Cohen, Mermelstein, Kamarck, \& Hoberman, 1985). Similarly, conflicted relationships make strong demands on emotion and the regulation of both the 
self and the partner (Levenson et al., 2003). All of this is consistent with Gross's (Gross, 1999) process model of emotion regulation, which is organized around the way people select situations, deploy attention, appraise events, and ultimately seek to control emotional responses.

There is no doubt these processes shape and are shaped by the interpersonal contexts in which they unfold, but extant theories on relationships and health, which we review below, also highlight the role of non-conscious, automatic processes for understanding myriad ways in which relationships may themselves shape affective experiences. Of course, affect and its regulation are intimately linked to our perception of the world, of prevailing contextual demands, of perceived effort, and even how we construe the meaning of things-including our own behavior and the behavior of our partners. Thus, in our view, the social dynamics of emotion and emotion-regulation are inextricably entwined with the way the world looks and feels to us, with our physiological responses to what we perceive, and to the behavior that ultimately determines so much about our health and wellbeing.

Toward a mediational model. Coan (2011) has argued that one way of understanding how social emotion regulation is related to health is to think in terms of a simple mediational model similar to the one outlined in Figure 1. In this schematic, social resources shape affective responses, which in turn shape health-relevant physiology, either directly or indirectly. We believe the "a path" in this model (see MacKinnon, 2007) requires unpacking. Precisely how do social resources-contexts, interactions with close others, and/or mental representations of relationships—sculpt affective responses? Efforts to answer this question are underway (e.g., Reeck et al. 2016), but this literature will benefit 
from a more complete connection to extant theories on relationships. In the next section, we offer a brief survey of these theories to identify principles, or components, that may provide a deeper understanding of the first step in our mediational model.

\section{Relationships and Health: A Review of the Theories}

A number of theoretical perspectives exist for understanding the large literature linking relationship status and quality to health (broadly defined). As we make clear below, most of the empirical evidence in this this area is multiply determined-for any given social process or interaction, each perspective provides a partial account of the same data. Consider, for example, meta-analytic findings that link high levels of marital quality to clinically-meaningful health outcomes (Robles et al., 2014). Multiple theoretical perspectives, including well-established ideas from the social support, appraisal theory, attachment, and social control of health behavior literatures, are needed to understand the corpus of research on marriage and health (e.g., Slatcher, 2016). It is equally likely that newer models-for example, ideas about relational information processing (described below) are also relevant. In this sub-section, we take stock of the prominent theories in the area of relationships and health. This brief review sets the stage for enumerating the crosscutting principles that describe the many ways in which social resources shape affective experiences. In advance of reviewing each of the nine theories, we encourage readers to think about commonalities and the ways in which the different theoretical perspectives may be describing similar underlying processes.

Social Baseline Theory (Beckes \& Coan, 2011; Coan \& Sbarra, 2015). Social Baseline Theory (SBT) presents an ecological view of how social relationships contribute to health and wellbeing, integrating perspectives from attachment theory, behavioral ecology, 
economics, Gibson's Theory of Affordances, and neuroscience (Coan \& Maresh, 2014; Gross \& Proffitt, 2013). SBT's first contention is that the human brain evolved to assume proximity to social relationships characterized by shared goals, interdependence, and trust. The term "assume" connotes adaptations built into the structure and function of the human body and brain, adaptations that render many of the brain's capabilities dependent on structured, interdependent social environments in order to function optimally.

SBT suggests the human brain reflexively construes relational partners as efficacyenhancing extensions of the self, which allows it to budget its cognitive and physiological resources as if the cognitive and physiological resources available to others were available to the self as well. This strategy economizes personal effort by establishing and maintaining social relationships that provide access to enhanced capabilities—by essentially empowering humans to outsource everything from probabilistic risk to threat vigilance, creative problem solving, emotion regulation, memory, physical labor, etc. According to SBT, then, proximity to social resources is inherently regulatory with regard to our propensity to engage in neural and behavioral work, with all of the subjective, emotional, and physiological sequelae that implies. Thus, when social resources are available, we assume that meeting environmental demands is less effortful, and adjust our efforts accordingly. When social resources are absent, unreliable, or lost, both our objective and subjective efficacy is diminished, and we must as a consequence marshal more personal resources to cope with prevailing demands. Subjectively, this is experienced as undesirable at best, and as acutely painful at worst (Eisenberger \& Lieberman, 2004).

\section{Attachment Theory: Normative and Coregulatory Models (Hofer, 1984; Sbarra}

\& Hazan, 2008). In the first book in his trilogy, the British Psychiatrist and father of 
attachment theory, John Bowbly (1969/1982), argued that understanding children's responses to separations from caregivers hinged on understanding the nature of the bond that "ties him to that figure" (p. 177). Here, Bowbly was arguing for the importance of understanding what it means to be attached to another person. The core of this normative approach is the regulation of felt security with another person, and in the process of attachment formation, children and adults alike move through a series of stages toward pair bond development toward this felt-security endpoint (Hazan \& Zeifman, 1994, 1999; Zeifman \& Hazan, 1997). At a biological level, Hofer (1984) provided critical insights on the psychobiology of caregiving. For example, in studies of mother-pup rat dyads, Hofer (1987) showed that specific components of the mother-pup interaction (e.g., tactile stimulation) regulated the pup's behavioral and physiological systems. Hofer (1984) referred to these regulators as "hidden" because it was not until they were removed, lost, or knocked-out in some capacity that their regulatory work was revealed. This idea was developed further by Sbarra and Hazan (2008), who posited that coregulation, defined as the reciprocal maintenance of functionally linked physiologies, was an emergent property of full-blown attachment relationships.

The term coregulation has many meanings, and there exists more theoretical speculation about its nature than empirical data (Butler \& Randall, 2013). At its core, however, the idea of biological interdependence presents a potential way in which relationships may be health protective. For example, a recent study of 32 heterosexual couples revealed positive partner effects on heart rate variability (HRV), a putative index of cardiac vagal control that is often used to index emotion regulatory capacity and flexibility, across a series of laboratory tasks (Helm, Sbarra, \& Ferrer, 2012; Helm, Sbarra, \& Ferrer, 
2014); not only were participants' HRV scores at a given occasion predicted by their prior HRV scores, but partners' earlier HRV predicted participants' subsequent scores as well. Importantly, the strength of the effect from one person's HRV at prior occasions to their partner's HRV at the next occasion was moderated by relationship quality, with people in more satisfied relationships showing stronger cross-partner, cross-time associations. The critical question for this line of research, and others like it (e.g., Saxbe \& Repetti, 2010), is whether this interdependence predicts distal health outcomes and provides a profitable means of understanding how coregulatory processes may be health protective.

Attachment Theory: Individual Differences. Normative accounts of attachment are complimentary to views that emphasize individual differences in trait-like dispositions toward others called attachment styles (Mikulincer \& Shaver, 2007) or attachment states of mind (Ainsworth, Blehar, Waters, \& Wall, 1978). These dispositions are thought to result from experiences that combined potential threats to the self (or threats to attachment relationships) with the presence, absence, or attachment-related behaviors of early attachment figures, usually caregivers. The past several decades have seen an explosion of research in this area, culminating (at least) in two psychometrically reliable axes often called attachment anxiety and attachment avoidance. These two axes can form a circumplex, with individuals falling within higher or lower levels on both, independently (Bartholomew \& Horowitz, 1991; Fraley, Waller, \& Brennan, 2000). Secure individuals are thought to be those who are low in both attachment anxiety and avoidance. It is this group that perhaps most closely manifests normative attachment behaviors as Bowlby and Ainsworth envisioned them. On the opposite end of the circumplex, individuals high in both anxiety and avoidance-often considered fearful-avoid attachments out of fear of 
rejection, harm or loss. Individuals low in avoidance but high in anxiety are said to be preoccupied with the status of their attachment relationships, often engaging in excessive reassurance seeking or jealous behavior (Guerrero, 1998; Holtzworth-Munroe, Stuart, \& Hutchinson, 1997). Finally, those low in anxiety but high in avoidance are said to be dismissive of attachment relationships, emphasizing self-reliance, and, perhaps, a view of others as cognitively or emotionally taxing.

Recently, Coan (2010) has suggested that the literature on attachment styles can be understood from the perspective of predictive coding (sometimes called the Bayesian Brain Hypothesis) within the brain — a general capacity to predict the availability and reliability of resources in making decisions about how to respond to environmental demands. Taking this view, attachment styles reflect the brain's predictions about the availability of social resources, as well as their potential costs and benefits (Coan, 2010). At their core, the attachment dimensions of anxiety and avoidance are emotion regulatory strategies (cf. Shaver \& Mikulincer, 2002), and these dimensions appear to have powerful predictive utility for understanding health outcomes from infancy to adulthood (Puig, Englund, Simpson, \& Collins, 2013). Furthermore, there is a growing literature on the role of attachment styles and health-relevant physiological responses (e.g.. Pietromonaco PR, Uchino, \& Dunkel Schetter, 2013). Recent work, for example, shows that attachment insecurity predicts cortisol patterns in response to laboratory-based stress (Pietromonaco, DeBuse, \& Powers, 2013); that attachment anxiety is associated with greater blood pressure reactivity when adults speak about their marital separation in an over-involved way (Lee et al., 2011); that attachment anxiety is associated with altered cellular immunity and immune dysregulation (Jaremka, Glaser, Loving, Malarkey, Stowell, \& Kiecolt-Glaser, 
2013); and that attachment anxiety is related to the expression of a latent herpes virus (Fagundes et al., 2014).

Evolutionary Model of Loneliness (Cacioppo \& Patrick, 2008). Loneliness, the subjective experience of social isolation, is associated with increased risk for a range of health morbidities and all-cause mortality (Holt-Lunstad, Smith, Baker, Harris, \& Stephenson, 2015). The evolutionary theory of loneliness holds that the aversive, felt experience of subjective isolation evolved to motivate people to take actions that promote social integration for self-preservation; just as physical pain evolved to minimize damage to the body, loneliness evolved because being socially embedded promotes survival, and the signal to reconnect to others is hypothesized to have adaptive value (Cacioppo, Cacioppo, \& Boomsma, 2014). A key aspect of this evolutionary theory is that loneliness promotes a high degree of vigilance for predatory risks and attentional shifts toward social threats (Cacioppo, Capitanio, \& Cacioppo, 2014). In the short-term, these strategies are adaptive, but if loneliness becomes chronic, the downstream consequences of this maintained vigilance include impaired sleep (Kurina et al., 2011) and a degree of physiological activation, including, for example, higher tonic vascular resistance (Cacioppo et al., 2002), that can be health damaging. A central question for future research is whether social vigilance operates mechanistically to predict health-relevant biological responding. For example, studies confirm gene expression differences between lonely and social embedded adults, with the lonely evidencing a relatively greater upregulation of genes associated with inflammatory signaling (Cole et al., 2007).

Social Evaluative Threat (SET; Dickerson \& Kemeny, 2004). In many respects, the SET model shares considerable overlap with the evolutionary theory of loneliness. 
According to Dickerson and Kemeny (2004), SET, “...occurs when an important aspect of the self-identity is or could be negatively judged by others" (p. 358), and others have extended this idea to include potential losses of social status and acceptance that might have the potential for rejection or ostracism (Dickerson, Gruenewald, \& Kemeny, 2004). At its core, SET hinges on vigilance for the potential loss of self-esteem or social status, and is most relevant to motivated performance situations (see Jamieson, Hangen, Lee, \& Yeager, 2017; Tomaka, Blascovich, Kelsey, \& Leitten, 1993) and contexts in which rejection can occur. The importance of perceived SET was first demonstrated in a large meta-analysis showing that acute, laboratory-based studies manipulating SET yielded significant increases in salivary or plasma cortisol, and this effect was especially strong when the SET occurs in situations with uncontrollable outcomes (Dickerson, Gruenewald, et al., 2004; Dickerson \& Kemeny, 2004). The general model is consistent with animal studies linking status within the social hierarchy as a critical variable for primate health (Sapolsky, 2005). Within the SET model, the social emotion of shame is believed to play a prominent role in orchestrating exaggerated physiological responses that are specific to social contexts (Dickerson, Kemeny, Aziz, Kim, \& Fahey, 2004). A series of recent experience sampling studies have demonstrated that SET in daily life is associated with heighted cardiovascular responding (e.g., Lehman, Cane, Tallon, \& Smith, 2014).

\section{Social Support- Stress Buffering and Main Effects (Cohen \& Willis, 1985;}

Uchino, 2004). The literature on social support and health is voluminous, and the science is clear in demonstrating that people who are more socially integrated demonstrate better physical health (Holt-Lunstad et al., 2010). Consistent with the larger theme of this review, the science of social support is steeped in the study of potential mechanisms. An important 
distinction in this literature is between the structure and function of support networks (Uchino, 2006). Structural elements refer to a person's location within social networks and focus on the size or density of these networks, but the functions of specific relationships within the network matter as well, and these functions include perceived/received support. Uchino (2006) suggests that the structural and functional elements of support networks may influence health through distinct (but not necessarily independent) pathways, with the former operating through behavioral processes (where relationships facilitate the social control of health behaviors) and the latter process operating through psychological processes (including appraisals, emotions and mood states, and feelings of control). These processes, in turn, influence cardiovascular, neuroendocrine, and immune responses that are associated with diseased endpoints (cf. Berkman et al., 2000).

An additional distinction in the social support literature is between the so-called direct and stress-buffering models (Cohen \& Wills, 1985), with the former suggesting support is beneficial regardless of stress levels and the latter suggesting that support acts a moderator to decrease the strength of the association between stress and physical health or physiological outcomes. Both models have empirical support (Holt-Lunstad \& Uchino, 2015) and continue to guide research in this area. One especially active and potentially generative line of research in this area is about ambivalent relationships, which are those characterized by both positive and negative feelings (Birmingham, Uchino, Smith, Light, \& Butner, 2015; Holt-Lunstad, Uchino, Smith, \& Hicks, 2007). For example, a recent study found greater coronary-artery calcification among people in marriages who viewed and were viewed by their spouse as ambivalent (Uchino, Smith, \& Berg, 2014). 


\section{Interpersonal Circumplex Models (Kiesler, 1997; Pincus \& Ansell, 2003; Smith,}

Glazer, Ruiz, \& Gallo, 2004). The Interpersonal Circumplex (IPC) model is organized around two broad dimensions: affiliation (friendliness vs. hostility) and control (dominance vs. passivity). Smith et al. (2004) noted that the IPC can "describe specific social stimuli, specific social responses, more stable features of the social environment, and individual differences in social behavior" (p. 1220). This theoretical perspective has generated a wealth of empirical data on how dimensions of relationship functioning may influence health (Smith, Baron, \& Caska, 2014). An important aspect of the IPC model is that it provides for an understanding of transactional cycles in which Partner 1's behaviors and experiences influence Partner 2's behaviors and experiences in a reciprocal loop that unfolds over time. This framework provides an excellent way to explicate how specific relationship behaviors may influence health-relevant physiology over time, and we return to this point below.

\section{Temporal Interpersonal Emotional Systems (TIES; Butler, 2011). The TIES}

model holds that in social contexts, the time-based (i.e., temporal) organization of emotional experience in one person is directly connected to the emotional experience of another person, and the interpersonal nature of emotional processes can be understood as constituting a dynamic system. To be sure, a dynamic systems perspective on close relationships is not new (Gottman, Swanson, \& Swanson, 2002; Kelley et al., 1983) but the TIES model emphasizes the social-functional role of emotions within relationship (see Campos et al., 2011; Levenson et al., 2013). Butler (2011), writes, for example, “... we deal with most of our survival problems in the context of close relationships. Emotions are proposed to be adaptations for dealing with specific problems related to the formation and 
maintenance of those relationships" (p. 369). The primary contribution of the TIES model is that it operationalizes the specific ways in which these processes may unfold, and many of these processes have the potential to inform our understanding of the mechanisms linking relationships to distal health outcomes. For example, morphostatic covariation refers to between-partner covariation around a stable set point (Butler \& Randall, 2013). Here we might study, for example, ways in which one person's daily subjective emotional experience limits the range of his/her partner's autonomic functioning, studied concurrently or in some lagged fashion (e.g., see Figure 1 in Butler, 2011). Many questions emanating from the TIES perspective remain understudied. For example, Butler (2011) notes that we do not yet know whether tighter coupling of emotional responses within couples represents healthy vs. unhealthy functioning. Although answers to this question are far from clear, the interpersonal dynamics outlined within the TIES framework has direct relevance for studying health-relevant biomarkers.

Social Control of Health Behavior (Umberson, 1987). An implicit thread running through this paper is that there are multiple pathways from the form and function of close relationships to health endpoints. Thus far, we have largely focused on interactions and emotional expressions that may be associated with (by either up- or down-regulating) potentially harmful physiological responses. For example, social support may limit emotional reactivity in the laboratory (Coan, Schaefer, \& Davidson, 2006; Edens, Larkin, \& Abel, 1992; O'Donovan \& Hughes, 2008), and many accounts of this effect focus on how people appraise the availability of social support. Beyond these perceptions of the availability of social resources, a large literature indicates that close relationships shape or constrain behavior in ways that can be both salubrious or catabolic (Skoyen, Blank, 
Corkery, \& Butler, 2013; Skoyebn, Kogan, Novak, \& Buter, 2012; Umberson, 1987;

Umberson, 1992; Umberson, Crosnoe, \& Reczek, 2010). Health behaviors-from the positive (physical exercise, balanced diet, medical adherence) to the negative (smoking, excessive alcohol, poor diet and weight gain)—explain a large proportion of the variance in morbidity and mortality (McGinnis, Williams-Russo, \& Knickman, 2002). The social control of health behaviors refers to efforts by one person to directly regulate the behavior of another person (by telling, reminding, or threatening another person in order to effect a health behavior change) or to indirectly influence that person through feeling of obligation and responsibility to others (Tucker, 2002).

In an extensive review of this topic, Umberson et al. (2010) discuss a lifecourse perspective on health behaviors and outline a model in which many health habits are established in childhood within a family largely from parental influences, are heavily influenced by peers and social norms in adolescents, organized by relationship partners within a marriage, then change once again for older adults who are more likely to lose these powerful forces in later life (Tucker, Klein, \& Elliott, 2004). One interesting aspect of this model is that relationships are thought to confer symbolic meaning in which people protect their own health in an effort to care for children-e.g., an adult who drinks to cope with insomnia may ultimately stop in an effort to improve his health for his children. This suggests a broader view of what social control is, and how it might work (see also Bloch, Haase, \& Levenson, 2014). An equally interesting line of work is about the ways in which efforts to control another person's behaviors may backfire and operate ironically to maintain unhealthy habits. For example, demand-withdraw interactions (Heavey, Layne, \& Christensen, 1993) are evidenced when one partner nags for, criticizes about and pursues 
change in a partner and the partner withdraws, distances or defends against that change, and a variety of treatment approaches target this dynamic in an effort to improve health (Rohrbaugh \& Shoham, 2011).

\section{Connecting Relationships to Health via Affect: Distilling the Mechanisms of Action}

The third section of our paper distills four affective "components," culled from the theories reviewed above (see Table 1), that we believe can provide a mechanistic and integrative account of the many ways relationships shape health through affective experience. As the table indicates, some of the theories speak to all four of the components, whereas others emphasize just a few. From our perspective, these components are necessary and possibly sufficient for connecting social resources to affective responses. Thus, Figure 2 enumerates the components that comprise and inform the "affective responses" of Figure 1's "a path." These components can explain a wide range of affective phenomena-that they are indeed among the building blocks of emotion, per se (cf., Coan, 2010) — while also guiding research questions and paradigms that are both novel and, hence, potentially quite generative. For example, components outlined in Table 1, and described below, direct our collective attention to everything from how social resources alter both visual perception and cognitive appraisals, to the ways in which tit-for-tat arguments between partners escalate and become both unproductive and unmanageable. In our opinion, the components outlined in Figure 2 provide an important cross-theoretical perspective for studying the ways in which relationships shape health and wellbeing.

Embodied information processing. Decades of research suggests perception is active, not passive. That is, we attend to some but not all of the possible sensory information available in any given situation, and the brain's "decision" about what to attend 
to often precedes perception itself-we in effect predict what is most important, and that prediction guides our attention and, thus, our perception (Simons \& Chabris, 1999). According to Gibson's Theory of Affordances (Gibson, 1979), our sensory apparatus has been shaped by natural selection to detect features in our environment that are relevant to our body's ability to take action in that environment. The Theory of Affordances has lead to embodied conceptualizations of cognition, which have primarily to do with how our bodies are shaped to interact with the environments to which they are adapted. It is in this sense that our bodies are primed by natural selection to "think" and "perceive" in bottom-up fashion, without necessitating complex and time-consuming information processing by the central nervous system. If it were necessary for us to attend to all possible sensory information in any given context, it would be difficult or impossible to do anything else.

Critically for our purposes, emotion plays a key role in directing attention and, thus, influencing perception. Access to social resources affects attention and perception via its impact on emotion. Imagine a child waiting to give blood at a doctor's office. There is a reasonably good possibility that the child will not be excited about the needle required for this process. Indeed, the child is likely to be feeling afraid of the needle. This fear is likely to direct the child's attention to the needle itself, and to the child's arm where the needle is likely to puncture the skin, and so forth, to the exclusion of other sensory information. Most readers would guess that the presence of a trusted and responsive parent would decrease the child's fear in this situation, and they would be right. Less appreciated is that this decrease in fear will affect the child's perception of the context-the degree to which the needle poses a threat, and the degree to which other aspects of the doctor's office (e.g., the doctor herself, the interesting posters on the wall) now warrant attention. Although these 
effects seem on reflection obvious and intuitive, it is important to understand how the brain takes information about social resources and translates that into changes in attentional and perceptual behavior.

Social resources may alter the brain's assessment of resources, including embodied bioenergetic resources, available to the self. Indeed, recent work suggests perception is scaled in terms of our body's action-related capabilities-that our body's ability to act on the environment in any given situation becomes part of the virtual "ruler" we use to scale perception into "units" - units of distance, units of weight, units of height and slant, and, perhaps most generally, units of overall demand, including threat (Proffitt and Linkenauger, 2013, though see Durgin et al., 2009 and also Proffitt, 2009).

Critically, this scaling is likely to involve not only the structural properties of our bodies at any given time, but also the physiological state of our bodies at any given time. For example, physical fitness is negatively associated with perceived distance (Zadra, Weltman, \& Proffitt, 2015) and higher percent body fat corresponds with greater perceived slant in staircases (Taylor-Covill \& Eves, 2015). Ongoing energy expenditures (as when running on a treadmill) even correspond with steadily increasing distance judgments (White, Shockley, \& Riley, 2013). In its incorporation of these findings, social baseline theory suggests that a key element of social relationships - at least in humans-is the assimilation of others into the self (Aron \& Aron, 1997; Lane Beckes, Coan, \& Hasselmo, 2013). This assimilation entails the assumption that resources available to close others essentially amount to resources also available to one's self, altering the scaling of our body's action-related capabilities and, thus, our perception of environmental affordances and demands. Accumulating evidence suggests this is indeed what happens (reviewed in Gross \& Proffitt, 
2013). For example, people estimate hills to be less steep while walking with a supportive friend (Schnall et al., 2008), or even after browsing a supportive friend's Facebook profile (Faulkner and Clore, 2012). Similarly, individuals estimate hills to be less steep even after being experimentally induced to feel understood by strangers (Oishi, Schiller, \& Gross, 2013). To return to our concrete example, when a parent is supporting a child whose blood is being drawn, the child's sense of resources available to the self is expanded, and the level of perceived threat attributable to the needle decreases much as we would expect the slant of a hill to decrease, and for the same reason.

Missing from many of these formulations is the role of emotional states as intermediaries between the presence of social resources and these shifts in perception (cf., Beckes and Coan, 2011). Insofar as emotional states provide rapid, heuristic information about the costs and benefits of a given action (Schwartz \& Clore, 1983; Zadra \& Clore, 2011), and insofar as a wide variety of social processes alter our emotional states (Coan, 2011; Levenson et al., 2013), social factors such as relative proximity to and reliability of social resources affect perception via changes in emotional state. Importantly, this change in perception is likely to guide action. Thus, proximity to social resources alters emotional responding, emotional responding alters perception of the environment, and the resulting perceptual response guides behavior, including everything from physiological responding (e.g., release of stress-related hormone and endocrine activity) to directly health-related actions (e.g., risky or health-enhancing behaviors). Our hypothetical child may not flinch as the needle punctures his skin, he may not cry out, he may even feel less pain (cf., Coan et al., 2006). This formulation suggests in turn that researchers interested in mechanisms linking social relationships to health may benefit from paying greater attention to precisely how 
emotional states mediate the association between proximity to social resources and our perception of contextual demands.

Appraisal processes. A basic tenet of several of the theories discussed above is that our appraisals of social resources informs the deployment of physiological resources for task demands, and this is consistent with the foundational idea of stress and coping theory: The objective characteristics of a stressful event are less important than a person's appraisal or evaluation of the event (Lazarus \& Folkman, 1984). Appraisal processes are a critical component in intrapersonal emotion regulation (see Gross, 1998; Gross and Munoz, 1995), and the extent to which we appraisal our social standing as threatened or tenuous drives emotional response to solve these adaptive challenges. For example, Cacioppo and colleagues (Cacioppo \& Patrick, 2008) argue that perceived social isolation (i.e., loneliness) is a warning signal that rivals physical pain in its adaptive value, signaling the need for action that moves a person toward a more embedded place in their social world. Similarly, perceptions of support or social standing are clearly critical for health (Lam \& Dickerson, 2013; Ruiz, Hutchinson, \& Terrill, 2008; Sapolsky, 2005; Uchino, 2006), and the thinking in this area points toward an appraisal-mediated model in which evaluations of social resources can drive health-relevant physiological responding. Appraisal shape emotional responding, and social contexts and contacts shape these appraisal processes (see Jamieson et al., 2017).

For the purposes of this review, we make a distinction between embodied information processing (described above) and appraisals, with the latter being more deliberate and effortful, although we are fully aware that primary and secondary appraisals can unfold outside of conscious awareness. Returning again to the example of the child in 
the doctor's office, the embodied perspective involves a change in the perceptual calculus (i.e., social resources mitigate the need for emotion regulatory coping), whereas the appraisal perspective alters the emotion regulatory calculus (e.g., "It's OK, mommy will make it all better."). Arguably, there is little distinction between a perceptual process and a primary appraisal. If the child's mother is relegated to the waiting area, the situation becomes more of a demand-i.e., it is perceived as a threat that necessitates some coping effort. From our perspective, distinguishing between perceptual and appraisal processes has utility for specifying competing hypotheses as to how social resources shape the evaluation of potential task or situational demands.

Contingent interaction. The primary contribution of interpersonal perspectives on relationships and health is their focus on overt behavior, and the reciprocally-determined ways in which one person's thoughts, feelings, and behaviors may influence his or her partner in a dynamic manner over time (Ruiz, Hamann, Coyne, \& Compare, 2006; Smith, et al., 2014). Expressions of humor, for example, may disarm relationship conflict and promote the expression of warmth. Gottman and colleagues' work (Gottman, Coan, Carrere, \& Swanson, 1998; Levenson \& Gottman, 1983) provides an excellent example of the ways in which affective expressions can influence and be influenced by a partner's overt behavior, and the conflict resolution paradigm has spurred interactional research in the area of relationships and health. Smith et al. (2011), for example, found that husbands' negative affect and husbands' rating of wives' controlling behavior, mediated the decline in wives' resting heart rate variability between a neutral and negative interaction task. Although a contingent interaction perspective contains a social-cognitive element, with people inferring and thinking about the behaviors and mental states of others, its promise 
rests in the explicit focus on behavior and, in particular, recursive dyadic behavior that may shape emotions and, ultimately, health-relevant physiology (also see Butler, 2011; Skoyen, et al., 2013).

Transactional perspectives. Whereas an interactive perspective focuses on the specific behaviors of each person in a relationship (and how these behaviors unfold in time), a transactional perspective holds that individuality can be lost in some contexts, and that the appropriate level of analysis may lie in the emergent properties of a relationship (Ruiz, et al., 2006). An excellent example of this process is transactive memory (Wegner, Erber, \& Raymond, 1991), the process through which couples naturally share memories, many of which are not accessible by one or the other individual at a given time, but may always be accessible when the individuals interact with one another. But transactive processes like these extend far beyond memory or even the kinds of regulatory processes emphasized in attachment theory (e.g., Finkel, Fitzsimmons, \& vanDellen, 2015). Humans appear to have been shaped through natural selection to be particularly capable of sophisticated social cognition (Amodio \& Frith, 2006), joint attention (Tomasello, Carpenter, \& Liszkowski, 2007), and shared intentionality (Fitzsimons \& Finkel, 2015; Tomasello, Carpenter, Call, Behne, \& Moll, 2005). Indeed, this suite of capabilities may alone account for various transactional phenomena, including cooperation (Warneken \& Tomasello, 2009), distributed cognition (Tomasello et al., 2005), collective IQ (Woolley, Chabris, Pentland, Hashmi, \& Malone, 2010), and the social regulation of emotion (Coan, 2011).

It is probably worth noting that transactive phenomena like these may not be as special as they seem. Economists have long made the distinction between exchange 
economies and economies of scale. Exchange economies are those in which goods and services are exchanged-as in “I'll scratch your back, you'll scratch mine." Economies of scale are those in which the cost of producing something or achieving some goal is decreased by the scale of operation used to produce or achieve it. Of the two, economies of scale most dramatically increase efficiency. For example, it is much more efficient to make a single meal for two people than to make two separate meals for two separate people, who may then engage in some kind of trading. In that sense, cooking dinner can be transactive. There are numerous examples of this in nature, not least the distribution of risk that obtains through simple safety in numbers. Indeed, an economy of scale applied to the regulation of core body temperature may have resulted in the evolution of endothermy"warm bloodedness" - via the sharing of body heat during social huddling (IJzerman et al., 2015). Recent research even hints at a neural mechanism: the brain's ability to construe familiar others as if those others are extensions of the self (Beckes et al., 2013). In any case, relational partners are certainly capable of efficiently pooling resources-including cognitive, affective, and physiological resources-toward the efficient achievement of an almost infinite number of potential goals. This capability creates an enormous pressure to form and maintain relationships-pressure enough to shape the human brain and body over both phylogeny and ontogeny to be dependent upon relationships for optimal functioning.

\section{Moving Forward: Empirical Examples for Studying Relationships, Affect, and Health}

A central argument of this paper is that the enumeration of the affective components outlined in Table 1 and Figure 2 will be generative for advancing the mechanistic study of relationships and health. In this final section, we provide three 
examples of new empirical studies that draw on these components. These examples are not meant to be exhaustive, of course, but they illustrate the potential promise of combining the components in new ways and, in particular, pursuing research that is not wed to a single theoretic tradition.

Before considering the empirical examples, however, it is worth pausing to consider what constitutes a relevant health outcome in the study of relationships and health. In a now seminal review of the literature in health psychology, Miller, Chen and Cole (2009) emphasize the importance of biological intermediaries - that is, the study of variables that can link psychosocial stress to a disease endpoint. We echo the importance of studying these intermediary processes and also believe it is possible to extend this line of thinking to psychological processes. Higher quality of life, for example, is associated with lower body mass index, lower basal concentrations of C-reactive protein (Steptoe, Demakakos, de Oliveira, \& Wardle, 2012), better sleep (Steptoe, O'Donnell, Marmot, \& Wardle, 2008), and decreased risk for early death (Netuveli, Pikhart, Bobak, \& Blane, 2012). When we study relationships and quality of life, then, we are studying a psychological intermediary in the chain from relationships to distal health outcomes. Importantly, not all psychological processes are health-relevant, and it is therefore incumbent upon a given researcher to link their psychological phenotype to an important health endpoint by considering the relevant meta-analytic literature.

A second critical point about health outcomes concerns studying physiology more generally. As we have written elsewhere (Sbarra \& Coan, 2013), what constitutes a healthrelevant outcome may not depend as much on what is studied so much as how. In psychophysiology, physiological indices are often treated as more or less objective proxies 
for a psychological state. By contrast, health psychology and psychosomatic medicine more routinely place physiological variables on the outcome side of an equation, an effort geared toward understanding the predictors of that outcome. We wish to emphasize here that it is not enough to simply study a physiological outcome; rather, it is critical to demonstrate that physiological effects are practically meaningful and related to clinical or disease endpoints. Consider, for example, Coan et al. (2006) who found that simple handholding can down regulate threat-related activity in the hypothalamus. We can, and should, be interested in this finding because we know from other work that hypothalamic activity is associated with stress-related neuroendocrine responses, and that the overproduction of cortisol is associated with myriad negative health outcomes. But we still do not know what level of hypothalamic activity, per se, is health relevant and practically meaningful. In the context of relationship science, this would indeed be an ideal question for future research.

\section{Example 1: Expanding the theoretical reach of relationship-relevant}

processes. Despite some noteworthy exceptions (e.g., transactive memory), studies of relationships tend to focus on emotional behaviors and experiences, per se. But it is almost certainly true that relationships influence a broader variety of behavioral and psychological phenomena, across a variety of contexts, even when those influences are mediated emotionally. A partial list of these phenomena includes visual perception, working memory, and cognitive performance. A deep reading of the theoretical approaches outlined above is consistent with this, though social baseline theory may be the most explicitly so. In any case, it seems likely that an individual's cognitive and perceptual capabilities vary as a function of everything from her overall level of social integration, to her early experiences with caregivers, her perceived level of social support, the quality of her primary 
relationship, and even to the presence or absence of her relational partner at any given time.

Viewing the impact of relationships from this broader perspective may even expand our understandings of how the human mind works. But there is also the real potential for bridging the gaps that do exist between broad theoretical views of the links between relationships and health. For example, in modeling relationship-health links, a distinction is often made between the direct socioaffective buffering mechanisms and those emphasizing the social control of individual health behaviors. This distinction may be more porous than commonly acknowledged. It is certainly possible, for example, that socioaffective processes influence the social control of individual health behaviors (or vice versa) in important ways (e.g., see Darby, Henniger, \& Harris, 2014).

Example 2: Does emotional coregulation have any relevance for health? Earlier we noted that Helm et al (2014) recently found evidence for interdependence in adult couples' HRV over time; specifically, one person's HRV at a prior occasion predicted their partner's HRV at the next occasion, and this effect was moderated by relationship quality, with people in more satisfied relationships evidencing stronger cross-partner, cross-time associations. The authors speculated that this process was one potential manifestation of human coregulation (see Sbarra \& Hazan, 2008), but, to date, there is no evidence that coregulation itself has any direct relevance for health. Part of the problem with the Helm et al. (2014) finding is that HRV, as an outcome variable, is not calibrated in a meaningful way that allows for a direct understanding of the potential health relevance of the findings.

One way to extend this line of work would be to conduct a dyadic ecological momentary assessment (EMA; cf., Shiffman, Stone, \& Hufford, 2008) study while tracking 
variability in ambulatory blood pressure (BP) responses. Blood pressure is an ideal outcome variable because of its clear clinical relevance. Following Helm et al. (2014), we could examine the daily interdependence of BP and determine if the so-called partner effect (i.e., the cross-time, cross-partner regression coefficient) is moderated by, for example, relationship satisfaction. In-and-of itself, a moderation effect would provide more specific insights into the health relevance of physiological interdependence, and many other interesting analyses can be conducted within this basic paradigm as well. For example, daily behaviors and perceptions of partner's behaviors can be included as mediators of interdependence, as can daily affective experience. Alternatively, the within-couple patterns of interdependence could be saved and used as between-person predictors of changes in other biomarkers of interest (e.g., proinflammatory cytokines).

Example 3: Changes in gene expression across social transitions. One of the most exciting set of findings in the area of relationships and health suggests that socialenvironmental conditions are associated with differential patterns of gene expression (Slavich \& Cole, 2013). On this topic, Slavich and Cole have written that the, “... ability for the central nervous system to regulate transcriptional dynamics is not accidental but rather part of a deep functional relationship between behavioral and biological responses that appear to have evolved to help protect individuals during times of physical threat" (p. 3). Most research in this area has focused on broad shifts in the expression of two major gene programs within immune cells-genes associated with the inflammatory response and genes associated with antiviral signaling. Bioinformatic analyses show, for example, that lonely adults (relative to people who perceive themselves to be socially embedded) overexpress proinflammatory gene motifs while down-regulating the expression of antiviral 
genes (Cole, 2009). This finding fits well within the evolutionary theory of loneliness: to the extent that loneliness may signal an increased likelihood of predation or injury, a broad shift toward a proinflammatory or defensive gene expression phenotype has considerable survival value.

One especially exciting element of this line of work surrounds the question of how the genome receives signals about a person's social standing. It is quite possible that psychological responses convey this message, but to date no research has explored this mediating process, largely because it will involve studying changes in gene expression over time. Consider, for example, questions that surround the so-called widowhood effect (Stroebe, Schut, \& Stroebe, 2007), defined as the increased likelihood of early death following the loss of a spouse or partner. One reasonable hypothesis for understanding the widowhood effect is that as people face their partner's death, they also experience a concomitant shift in gene expression that heightens levels of proinflammatory cytokines, which have clear relevance for later disease pathophysiology (Ridker, Cushman, Stampfer, Tracy, \& Hennekens, 1998; Ridker, Glynn, \& Hennekens, 1998; Ridker, Rifai, Stampfer, \& Hennekens, 2000). In this case, we can make a very specific hypothesis: Gene expression patterns should be correlated with psychological, including affective, responses to the loss - i.e., adults' grief responses (cf. O’Connor, Schultze-Florey, Irwin, Arevalo, \& Cole, 2014).

A stronger version of the hypothesis would be that during a period of acute mourning, we would expect greater proinflammatory gene expression, but as grief subsides, we should also observe a corresponding change in gene expression patterns. This perspective is informed directly by the affective components identified above: As social contexts shift, and perhaps especially as relationships end, we expect affective changes to 
produce shifts in embodied perception of environmental demand and other appraisals, driving in turn a set of biological changes that may point to (and explain) health-relevant concerns measured at a later time. It is equally likely that as gene transcription motifs shift from, say, a pattern of inflammatory gene upregulation over the course of mourning, interaction and even transcactive processes are related to this change; as people reengage with others, these behaviors provide the critical input for recalibrated gene expression.

\section{Concluding Remarks}

The impetus for this review is a simple and important fact: Across the lifespan, close relationships and social connection are central to human health. This fact creates an ongoing need for new and innovative research that can advance our understanding of the many ways relationships shape health. This paper argues that affect plays a key mechanistic role in the relationship-health association and outlines four affective components (embodied information processing; appraisal processes; contingent interactions; and, transactional perspectives) that we believe hold promise for advancing new work in this area. These components provide an important cross-theoretical perspective for studying the ways in which relationships shape emotional responses and affective experiences that, in turn, have implications for health and wellbeing. Finally, we highlighted three empirical study ideas that illustrate the exciting promise that rests in combing these components in new and interesting ways. 


\section{References}

Ainsworth, M. D. S., Blehar, M. C., Waters, E., \& Wall, S. (1978). Patterns of attachment: A psychological study of the Strange Situation. Hillsdale, NJ: Lawrence Earlbaum Associates, Inc.

Amodio, D. M., \& Frith, C. D. (2006). Meeting of minds: The medial frontal cortex and social cognition. Nature Reviews Neuroscience, 7, 268-277.

Aron, A., \& Aron, E. N. (1997). Self-expansion motivation and including other in the self. In S. Duck (Ed.), Handbook of personal relationships: Thepry, research and interventions (pp. 251-270). Washington, DC: American Psychological Association.

Barrett, LF (2014). The Conceptual Act Theory: A précis. Emotion Review, 6, 292-297.

Bartholomew, K., \& Horowitz, L. M. (1991). Attachment styles among young adults: A test of a four category mode. Journal of Personality and Social Psychology, 61, 226-244.

Beckes, L., \& Coan, J. A. (2011). Social Baseline Theory: The role of social proximity in emotion and economy of action. Social and Personality Psychology Compass, 5, 976988.

Beckes, L., Coan, J. A., \& Hasselmo, K. (2013). Familiarity promotes the blurring of self and other in the neural representation of threat. Social Cognitive and Affective

Beckes, L., Coan, J. A., \& Morris, J. P. (2013). Implicit conditioning of faces via the social regulation of emotion: ERP evidence of early attentional biases for security conditioned faces. Psychophysiology, 50, 734-742.

Berkman, L., \& Kawachi, I. (2014). A historical framework for social epidemiology. In L. Berkman, I. Kawachi \& M. M. Glymour (Eds.), Social Epidemiology (2nd Edition) (pp. 1-17). Oxford, UK: Oxford University Press. 
Berkman, L. F., Glass, T., Brissette, I., \& Seeman, T. E. (2000). From social integration to health: Durkheim in the new millennium. Social Science \& Medicine, 51, 843-857.

Birmingham, W. C., Uchino, B. N., Smith, T. W., Light, K. C., \& Butner, J. (2015). It's complicated: Marital ambivalence on ambulatory blood pressure and daily interpersonal functioning. Annals of Behavioral Medicine, 49, 743-753.

Bloch, L., Haase, C. M., \& Levenson, R. W. (2014). Emotion regulation predicts marital satisfaction: More than a wives' tale. Emotion, 14(1), 130-144.

Bourassa, K. J., Memel, M., Woolverton, C., \& Sbarra, D. A. (2015a). A dyadic approach to health, cognition, and quality of life in aging adults. Psychology and Aging, 30, 449461.

Bourassa, K. J., Memel, M., Woolverton, C., \& Sbarra, D. A. (2015b). Social participation predicts cognitive functioning in aging adults over time: comparisons with physical health, depression, and physical activity. Aging \& Mental Health, DOI: $10.1080 / 13607863.2015 .1081152$

Bowlby, J. (1969/1980). Attachment and loss: Vol 1: Attachment (2nd ed.). New York: Basic Books.

Butler, E. A. (2011). Temporal Interpersonal Emotion Systems: The “TIES" the form relationships. Personality and Social Psychology Review, 15, 367-393.

Butler, E. A., \& Randall, A. K. (2013). Emotional coregulation in close relationships. Emotion Review, 5, 202-210.

Cacioppo, J. T., Cacioppo, S., \& Boomsma, D. I. (2014). Evolutionary mechanisms for loneliness. Cognition \& Emotion, 28, 3-21. 
Cacioppo, J. T., Cacioppo, S., Cole, S. W., Capitanio, J. P., Goossens, L., \& Boomsma, D. I. (2015). Loneliness across phylogeny and a call for comparative studies and animal models. Perspectives on Psychological Science, 10, 202-212.

Cacioppo, J. T., Hawkley, L. C., Crawford, E., Ernst, J. M., Burleson, M. H., Kowalewski, R. B., . . . Berntson, G. G. (2002). Loneliness and health: Potential mechanisms. Psychosomatic Medicine, 64, 407-417.

Cacioppo, J. T., \& Patrick, W. (2008). Loneliness: Human nature and the need for social connection. New York: WW Norton \& Company.

Cacioppo, S., Capitanio, J. P., \& Cacioppo, J. T. (2014). Toward a neurology of loneliness. Psychological Bulletin, 140, 1464-1504.

Cacioppo, S., Grippo, A. J., London, S., Goossens, L., \& Cacioppo, J. T. (2015). Loneliness Clinical Import and Interventions. Perspectives on Psychological Science, 10, 238-249.

Campos, J. J., Walle, E. A., Dahl, A., \& Main, A. (2011). Reconceptualizing emotion regulation. Emotion Review, 3, 26-35.

Champagne, F. A., \& Curley, J. P. (2009). Epigenetic mechanisms mediating the long-term effects of maternal care on development. Neuroscience \& Biobehavioral Reviews, 33, 593-600.

Chida, Y., \& Steptoe, A. (2008). Positive psychological well-being and mortality: A quantitative review of prospective observational studies. Psychosomatic Medicine, 70, 741-756. 
Chida, Y., \& Steptoe, A. (2010). Greater cardiovascular responses to laboratory mental stress are associated with poor subsequent cardiovascular risk status a metaanalysis of prospective evidence. Hypertension, 55, 1026-1032.

Clore, G. L., Gasper, K., \& Garvin, E. (2001). Affect as information. In J. P. Forgas (Ed.), Handbook of affect and social cognition (pp. 121-144). New York: Lawrence Erlbaum Associates, Publishers.

Clore, G. L., \& Tamir, M. (2002). Affect as embodied information. Psychological Inquiry, 13, $37-45$.

Clore, G. L., \& Ortony, A. (2000). Cognition in emotion: Never, sometimes, or always? In R. D. Lane \& L. Nadel (Eds.). The cognitive neuroscience of emotion (pp. 24-61). New York: Oxford University Press.

Coan, J.A. (2010). Emergent ghosts of the emotion machine. Emotion Review, 2, 274-285.

Coan, J. A. (2011). The social regulation of emotion. In J.Decety and J. T. Cacioppo (Eds.) Oxford Handbook of Social Neuroscience (pp.614-623). New York, Oxford University Press.

Coan, J. A. (2010). Adult attachment and the brain. Journal of Social and Personal Relationships, 27, 210-217.

Coan, J.A. \& Maresh, E.L. (2014). Social baseline theory and the social regulation of emotion. In J. Gross (Ed.) The Handbook of Emotion Regulation, 2nd Edition (pp. 221-236). New York: The Guilford Press.

Coan, J. A., \& Sbarra, D. A. (2015). Social Baseline Theory: The social regulation of risk and effort. Current Opinion in Psychology, 1, 87-91. 
Coan, J. A., Schaefer, H. S., \& Davidson, R. J. (2006). Lending a hand: Social regulation of the neural response to threat. Psychological Science, 17, 1032-1039.

Cohen, S., \& Janicki-Deverts, D. (2009). Can we improve our physical health by altering our social networks? Perspectives on Psychological Science, 4, 375-378.

Cohen, S., Mermelstein, R., Kamarck, T., \& Hoberman, H. M. (1985). Measuring the functional components of social support. In I. G. Sarason \& B. R. Sarason (Eds.), Social support: Theory, research and applications (pp. 73-94). Dordrecht: Martinus Nijhoff Publishers.

Cohen, S., \& Pressman, S. D. (2006). Positive affect and health. Current Directions in Psychological Science, 15, 122-125.

Cohen, S., \& Rodriguez, M. S. (1995). Pathways linking affective disturbances and physical disorders. Health Psychology, 14, 374-380.

Cohen, S., \& Willis, T. A. (1985). Stress, social support and the buffering hypothesis. Psychological Bulletin, 98, 310-335.

Cole, S. W. (2009). Social regulation of human gene expression. Current Directions in Psychological Science, 18, 132-137.

Cole, S. W., Hawkley, L. C., Arevalo, J. M., Sung, C. Y., Rose, R. M., \& Cacioppo, J. T. (2007). Social regulation of gene expression in human leukocytes. Genome Biol, 8, R189.

Darby, R.S., Henniger, N. \& Harris, C.R. (2014). Shame and guilt: Differential health outcomes in physician-patient interactions. Basic and Applied Social Psychology, 36, 9-26.

DeSteno, D., Gross, J. J., \& Kubzansky, L. (2013). Affective science and health: The importance of emotion and emotion regulation. Health Psychology, 32, 4744-86. 
Dickerson, S. S., Gruenewald, T. L., \& Kemeny, M. E. (2004). When the social self is threatened: Shame, physiology, and health. Journal of Personality, 72, 1191-1216.

Dickerson, S. S., \& Kemeny, M. E. (2004). Acute stressors and cortisol responses: A theoretical integration and synthesis of laboratory research. Psychological Bulletin, 130, 355-391.

Dickerson, S. S., Kemeny, M. E., Aziz, N., Kim, K. H., \& Fahey, J. L. (2004). Immunological effects of induced shame and guilt. Psychosomatic Medicine, 66, 124-131.

Durgin, F. H., Baird, J. A., Greenburg, M., Russell, R., Shaughnessy, K., \& Waymouth, S. (2009). Who is being deceived? The experimental demands of wearing a backpack. Psychonomic Bulletin \& Review, 16, 964-969.

Edens, J. L., Larkin, K. T., \& Abel, J. L. (1992). The effect of social support and physical touch on cardiovascular reactions to mental stress. Journal of Psychosomatic Research, 36, 371-381.

Eisenberger, N. I., \& Lieberman, M. D. (2004). Why rejection hurts: a common neural alarm system for physical and social pain. Trends in Cognitive Sciences, 8, 294-300.

Fagundes, C. P., Jaremka, L. M., Glaser, R., Alfano, C. M., Povoski, S. P., Lipari, A. M., . . Farrar, W. B. (2014). Attachment anxiety is related to Epstein-Barr Virus latency. Brain, Behavior, and Immunity, 41, 232-238.

Faulkner, L., \& Clore, G. 2012. Facebook friends with benefits: Online social support and slant perception. Honor's Thesis, University of Virginia. Retrieved January 11, 2014, from http://www.virginia.edu/

Fitzsimons, G. M., Finkel, E. J., \& Vandellen, M. R. (2015). Transactive goal dynamics. Psychological review, 122, 648-673. 
Fitzsimons, G. M., \& Finkel, E. J. (2015). Goal interdependence. Current Opinion in Psychology, 1, 10-13.

Fraley, R. C., Waller, N. G., \& Brennan, K. A. (2000). An item response theory analysis of selfreport measures of adult attachment. Journal of Personality \& Social Psychology, 78, $350-365$.

Gibson, J. (1979). The theory of affordances: An ecological approach to visual perception. Boston: Houghton Miffin.

Gosling, S. D. (2008). Personality in non-human animals. Social and Personality Psychology Compass, 2, 985-1001.

Gosling, S. D., \& John, O. P. (1999). Personality dimensions in nonhuman animals a crossspecies review. Current Directions in Psychological Science, 8, 69-75.

Gottman, J., Swanson, C., \& Swanson, K. (2002). A general systems theory of marriage: Nonlinear difference equation modeling of marital interaction. Personality and Social Psychology Review, 6, 326-340.

Gottman, J. M., Coan, J., Carrere, S., \& Swanson, C. (1998). Predicting marital happiness and stability from newlywed interactions. Journal of Marriage and Family, 60, 5-22.

Granovetter, M. (1983). The strength of weak ties: A network theory revisited. Sociological theory, 1, 201-233.

Greenwald, A. G., Pratkanis, A. R., Leippe, M. R., \& Baumgardner, M. H. (1986). Under what conditions does theory obstruct research progress? Psychological Review, 93, 216229. 
Gross, E. B., \& Proffitt, D. (2013). The economy of social resources and its influence on spatial perceptions. Frontiers in human neuroscience, Published online 2013 Nov 19. doi: 10.3389/fnhum.2013.00772

Gross, J. J. (1998). Antecedent-and response-focused emotion regulation: Divergent consequences for experience, expression, and physiology. Journal of Personality and Social Psychology, 74, 224.-237,

Gross, J. J. (1999). Emotion regulation: Past, present, future. Cognition \& Emotion, 13, 551573.

Gross, J. J., \& Muñoz, R. F. (1995). Emotion regulation and mental health. Clinical Psychology: Science and Practice, 2, 151-164.

Gross, J. J., Richards, J. M., \& John, O. P. (2006). Emotion regulation in everyday life. In D. K. Snyder, J. A. Simpson \& J. N. Hughes (Eds.), Emotion regulation in couples and families: Pathways to dysfunction and health (pp. 13-35). Washington, DC: American Psychological Association.

Graydon, M. M., Linkenauger, S. A., Teachman, B. A., \& Proffitt, D. R. (2012). Scared stiff: The influence of anxiety on the perception of action capabilities. Cognition \& Emotion, $26,1301-1315$.

Guerrero, L. K. (1998). Attachment-style differences in the experience and expression of romantic jealousy. Personal Relationships, 5, 273-291.

Gump, B. B., Polk, D. E., Kamarck, T. W., \& Shiffman, S. M. (2001). Partner interactions are associated with reduced blood pressure in the natural environment: Ambulatory monitoring evidence from a healthy, multiethnic adult sample. Psychosomatic Medicine, 63, 423-433. 
Harlow, H. F., \& Zimmermann, R. R. (1959). Affectional responses in the infant monkey. Science, $130,421-432$.

Harris, C. B., Barnier, A. J., Sutton, J., \& Keil, P. G. (2014). Couples as socially distributed cognitive systems: remembering in everyday social and material contexts. Memory Studies, 7, 285-297.

Hatfield, E., \& Walster, G. W. (1978). A new look at love. Lantham, MA: University Press of America.

Hazan, C., \& Zeifman, D. (1994). Sex and the psychological tether. In K. Bartholomew \& D. Perlman (Eds.), Attachment processes in adulthood. (pp. 151-178). London: Jessica Kingsley.

Hazan, C., \& Zeifman, D. (1999). Pair bonds as attachments: Evaluating the evidence. In J. Cassidy \& P. R. Shaver (Eds.), Handbook of attachment: Theory, research, and clinical applications. (pp. 336-354). New York: The Guilford Press.

Heavey, C. L., Layne, C., \& Christensen, A. (1993). Gender and conflict structure in marital interaction: a replication and extension. Journal of Consulting and Clinical Psychology, 61(1), 16-27.

Helm, J. L., Sbarra, D., \& Ferrer, E. (2012). Assessing cross-partner associations in physiological responses via coupled oscillator models. Emotion, 12, 748.

Helm, J. L., Sbarra, D. A., \& Ferrer, E. (2014). Coregulation of respiratory sinus arrhythmia in adult romantic partners. Emotion, 14, 522-531.

Hernandez, R., Bassett, S., Boughton, S., Schuette, S., Shiu, E., \& Moskowitz, J. (in press). Psychological well-being and physical health: Associations, mechanisms, and future directions. Emotion Review. 
Hofer, M. A. (1984). Relationships as regulators: A psychobiological perspective on bereavement. Psychosomatic Medicine, 46, 183-197

Hofer, M. A. (1987). Early social relationships: A psychobiologist's view. Child Development, $58,633-647$.

Hofer, M. A. (2006). Psychobiological Roots of Early Attachment. Current Directions in Psychological Science, 15, 84-88.

Holt-Lunstad, J., Smith, T., \& Layton, J. (2010). Social Relationships and Mortality Risk: A Meta-analytic Review. pmed. 1000316, 7(7), e1000316.

Holt-Lunstad, J., Smith, T. B., Baker, M., Harris, T., \& Stephenson, D. (2015). Loneliness and social isolation as risk factors for mortality: A meta-analytic review. Perspectives on Psychological Science, 10, 227-237.

Holt-Lunstad, J., \& Uchino, B. (2015). Social support and health. In K. Glanz, B.K. Rimer, \& K. Viswanath, Health behavior: Theory, research, \& practice (pp. 183-204). New York: Jossey-Bass.

Holt-Lunstad, J., Smith, T., \& Layton, J. (2010). Social relationships and mortality risk: A meta-analytic review. PLoS Medicine. 1000316, 7(7), e1000316.

Holt-Lunstad, J., Uchino, B. N., Smith, T. W., \& Hicks, A. (2007). On the importance of relationship quality: The impact of ambivalence in friendships on cardiovascular functioning. Annals of Behavioral Medicine, 33, 278-290.

Holtzworth-Munroe, A., Stuart, G. L., \& Hutchinson, G. (1997). Violent versus nonviolent husbands: Differences in attachment patterns, dependency, and jealousy. Journal of Family Psychology, 11, 314. 
Idler, E. L., Boulifard, D. A., \& Contrada, R. J. (2012). Mending broken hearts marriage and survival following cardiac surgery. Journal of Health and Social Behavior, 53, 33-49.

IJzerman, H., Coan, J. A., Wagemans, F. M., Missler, M. A., Van Beest, I., Lindenberg, S., \& Tops, M. (2015). A theory of social thermoregulation in human primates. Frontiers in Psychology, 6, doi: 10.3389/fpsyg.2015.00464.

Jamieson, J. P., Hangen, E.J., Lee, H.Y., Yeager, D.S. (in press). Capitalizing on appraisal processes to improve social stress responses. Emotion Review.

Jaremka, L. M., Glaser, R., Loving, T. J., Malarkey, W. B., Stowell, J. R., \& Kiecolt-Glaser, J. K. (2013). Attachment anxiety is linked to alterations in cortisol production and cellular immunity. Psychological Science, 24, 272-279.

Kawachi, I., Colditz, G. A., Ascherio, A., Rimm, E. B., Giovannucci, E., Stampfer, M. J., \& Willett, W. C. (1996). A prospective study of social networks in relation to total mortality and cardiovascular disease in men in the USA. Journal of Epidemiology and Community Health, 50, 245-251.

Kelley, H. H., Bersheid, E., Christensen, A., Harvey, J. H., Huston, T. L., Levinger, G., . . . Peterson, D. R. (1983). Close relationships. New York: W.H. Freeman and Company.

Keltner, D., \& Haidt, J. (1999). Social functions of emotions at four levels of analysis. Cognition \& Emotion, 13(5), 505-521.

Kenny, D. A., Kashy, D. A., \& Cook, W. L. (2006). Dyadic data analysis. New York: Guilford Press.

Kiecolt-Glaser, J. K., McGuire, L., Robles, T. F., \& Glaser, R. (2002). Emotions, morbidity, and mortality: New perspectives from psychoneuroimmunology. Annual Review of Psychology, 53, 83-107. 
Kiesler, D. J. (1997). Contemporary interpersonal theory and research: Personality, psychopathology, and psychotherapy (Vol. 6). New York: John Wiley and Sons.

King, J. E., \& Figueredo, A. J. (1997). The five-factor model plus dominance in chimpanzee personality. Journal of Research in Personality, 31, 257-271.

Kraus, M. W., Huang, C., \& Keltner, D. (2010). Tactile communication, cooperation, and performance: an ethological study of the NBA. Emotion, 10, 745-749.

Kurina, L. M., Knutson, K. L., Hawkley, L. C., Cacioppo, J. T., Lauderdale, D. S., \& Ober, C. (2011). Loneliness is associated with sleep fragmentation in a communal society. Sleep, 34, 1519-1526.

Kubzansky, L. D., Cole, S. R., Kawachi, I., Vokonas, P., \& Sparrow, D. (2006). Shared and unique contributions of anger, anxiety, and depression to coronary heart disease: A prospective study in the normative aging study. Annals of Behavioral Medicine, 31, 21-29.

Kubzansky, L., Winning, A., \& Kawachi, I. (2014). Affective states and health. In L. Berkman, I. Kawachi \& M. M. Glymour (Eds.), Social epidemiology (2nd edition) (pp. 320-364). Oxford, UK: Oxford University Press.

Lam, S., \& Dickerson, S. S. (2013). Social relationships, social threat, and health. In M. L. Newman \& N. A. Roberts (Eds.), Health and social relationships: The good, the bad, and the complicated (pp. 19-38). Washington, DC: American Psychological Association.

Lazarus, R. S., \& Folkman, S. (1984). Stress, appraisal, and coping. New York: Springer. 
Lazer, D., Pentland, A. S., Adamic, L., Aral, S., Barabasi, A. L., Brewer, D., ... Gutmann, M. (2009). Life in the network: The coming age of computational social science. Science, $323,721-723$.

Lee, L. A., Sbarra, D. A., Mason, A. E., \& Law, R. W. (2011). Attachment anxiety, verbal immediacy, and blood pressure: Results from a laboratory analog study following marital separation. Personal Relationships, 18, 285-301.

Lehman, B. J., Cane, A. C., Tallon, S. J., \& Smith, S. F. (2014). Physiological and emotional responses to subjective social evaluative threat in daily life. Anxiety, Stress, \& Coping, 28, 321-339.

Levenson, R. W., \& Gottman, J. M. (1983). Marital interaction: Physiological linkage and affective exchange. Journal of Personality \& Social Psychology, 45, 587-594.

Levenson, R. W., Haase, C. M., Bloch, L., Holley, S. R., \& Seider, B. H. (2013). Emotion regulation in couples. In J. J. Gross (Ed.), Handbook of emotion regulation (Vol. 2nd Edition, pp. 267-283). New York: Guilford Pres

MacKinnon, D. P., Fairchild, A. J., \& Fritz, M. S. (2007). Mediation analysis. Annual Review of Psychology, 58, 593-614.

Meaney, M. J., \& Szyf, M. (2005). Environmental programming of stress responses through DNA methylation: life at the interface between a dynamic environment and a fixed genome. Dialogues in Clinical Neuroscience, 7, 103-23.

McGinnis, J. M., Williams-Russo, P., \& Knickman, J. R. (2002). The case for more active policy attention to health promotion. Health Affairs, 21, 78-93. 
Mikulincer, M., \& Shaver, P. R. (2005). Attachment theory and emotions in close relationships: Exploring the attachment-related dynamics of emotional reactions to relational events. Personal Relationships, 12, 149-168.

Mikulincer, M., \& Shaver, P. R. (2007). Attachment in adulthood: Structure, dynamics, and change. New York: Guilford Press.

Miller, G., Chen, E., \& Cole, S. W. (2009). Health psychology: Developing biologically plausible models linking the social world and physical health. Annual Review of Psychology, 60, 501-524.

Miller, G. E., Cohen, S., \& Ritchey, A. K. (2002). Chronic psychological stress and the regulation of pre-inflammatory cytokines: A glucocorticoid-resistance model. Health Psychology, 21, 531-541.

Morris, M.W. and Keltner, D. (2000) How emotions work: The social functions of emotional expression in negotiations. Research in Organizational Behavior, 22, 1-50

Netuveli, G., Pikhart, H., Bobak, M., \& Blane, D. (2012). Generic quality of life predicts allcause mortality in the short term: evidence from British Household Panel Survey. Journal of Epidemiology and Community Health, 66, 962-966.

Niven, K., Totterdell, P., \& Holman, D. (2009). A classification of controlled interpersonal affect regulation strategies. Emotion, 9, 498.-509.

Noftle, E. E., \& Shaver, P. R. (2006). Attachment dimensions and the big five personality traits: Associations and comparative ability to predict relationship quality. Journal of Research in Personality, 40, 179-208. 
O'Donovan, A., \& Hughes, B. M. (2008). Access to social support in life and in the laboratory combined impact on cardiovascular reactivity to stress and state anxiety. Journal of Health Psychology, 13, 1147-1156.

O’Connor, M.-F., Schultze-Florey, C. R., Irwin, M. R., Arevalo, J. M., \& Cole, S. W. (2014). Divergent gene expression responses to complicated grief and non-complicated grief. Brain, Behavior, and Immunity, 37, 78-83.

Oishi, S., Schiller, J., \& Gross, E. B. (2013). Felt understanding and misunderstanding affect the perception of pain, slant, and distance. Social Psychological and Personality Science, 4, 259-266.

Ortman, J. M., Velkoff, V. A., \& Hogan, H. (2014). An aging nation: the older population in the United States. Washington, DC: US Census Bureau, 25-1140.

Parkinson, B., Fischer, A. H., \& Manstead, A. S. (2004). Emotion in social relations: Cultural, group, and interpersonal processes. Psychology Press.

Pietromonaco, P. R., DeBuse, C. J., \& Powers, S. I. (2013). Does attachment get under the skin? Adult romantic attachment and cortisol responses to stress. Current Directions in Psychological Science, 22, 63-68.

Pietromonaco, P. R., Uchino, B., \& Dunkel Schetter, C. (2013). Close relationship processes and health: Implications of attachment theory for health and disease. Health Psychology, 32, 499-513.

Phelps, E. A., Lempert, K. M., \& Sokol-Hessner, P. (2014). Emotion and decision making: multiple modulatory neural circuits. Annual Review of Neuroscience, 37, 263-287. 
Pincus, A. L., \& Ansell, E. B. (2003). Interpersonal theory of personality. In T. Millon \& M. J. Lerner (Eds.), Handbook of psychology, Vol 5., Personality and social psychology (pp. 209-229). New York: John Wiley.

Puig, J., Englund, M. M., Simpson, J. A., \& Collins, W. A. (2013). Predicting adult physical illness from infant attachment: A prospective longitudinal study. Health Psychology, 32, 409.

Proffitt, D. R. (2009). Affordances matter in geographical slant perception. Psychonomic Bulletin and Review, 16, 970-972.

Reeck, C., Ames, D. R., \& Ochsner, K. N. (2016). The social regulation of emotion: An integrative, cross-disciplinary model. Trends in cognitive sciences, 20, 47-63.

Reis, H. T., Collins, W. A., \& Berscheid, E. (2000). The relationship context of human behavior and development. Psychological Bulletin, 126, 844-872.

Ridker, P. M., Cushman, M., Stampfer, M. J., Tracy, R. P., \& Hennekens, C. H. (1998). Plasma concentration of C-reactive protein and risk of developing peripheral vascular disease. Circulation, 97, 425-428.

Ridker, P. M., Glynn, R. J., \& Hennekens, C. H. (1998). C-reactive protein adds to the predictive value of total and HDL cholesterol in determining risk of first myocardial infarction. Circulation, 97(20), 2007-2011.

Ridker, P. M., Rifai, N., Stampfer, M. J., \& Hennekens, C. H. (2000). Plasma concentration of interleukin- 6 and the risk of future myocardial infarction among apparently healthy men. Circulation, 101, 1767-1772.

Rimé, B. (2007). Interpersonal emotion regulation. J.J. Gross (Editor), Handbook of emotion regulation (466-487). New York: Guilford Press. 
Robles, T. F., Slatcher, R. B., Trombello, J. M., \& McGinn, M. M. (2014). Marital quality and health: A meta-analytic review. Psychological Bulletin, 140, 140-187.

Rohrbaugh, M. J., \& Shoham, V. (2011). Family consultation for couples coping with health problems: A social-cybernetic approach. In H. S. Friedman (Ed.), Oxford handbook of Health Psychology (pp. 480-501). New York: Oxford University Press.

Ruiz, J., Hamann, H., Coyne, J., \& Compare, A. (2006). In sickness and in health: Interpersonal risk and resilience in cardiovascular disease. In M. Molinari, G. Parati, \& A. Comare (Eds), Clinical psychology and heart disease (pp. 233-272). Milan, Italy: Springer-Verlag.

Ruiz, J. M., Hutchinson, J. G., \& Terrill, A. L. (2008). For better and worse: Social influences on coronary heart disease risk. Social and Personality Psychology Compass, 2, 14001414.

Sapolsky, R. M. (2005). The influence of social hierarchy on primate health. Science, 308, 648-652.

Saxbe, D., \& Repetti, R. L. (2010). For better or worse? Coregulation of couples' cortisol levels and mood states. Journal of Personality and Social Psychology, 98, 92-103.

Sbarra, D. (2015). Divorce and health: Current trends and future directions. Psychosomatic Medicine, 77, 227-236.

Sbarra, D. A., \& Coan, J. A. (2013). Theory, method, and prediction in the psychophysiology of relationships. International Journal of Psychophysiology, 88, 219-223.

Sbarra, D. A., \& Hazan, C. (2008). Coregulation, dysregulation, and self-regulation: An integrative analysis and empirical agenda for understanding attachment, separation, loss, and recovery. Personality \& Social Psychology Review, 12, 141-167. 
Scherer, K. R. (1984). On the nature and function of emotion: A component process approach. In K. R. Scherer \& P. Ekman (Eds.), Approaches to emotion (pp. 293-317). New York: Guilford Pres.

Schoebi, D., \& Randall, A. K. (2015). Emotional dynamics in intimate relationships. Emotion Review, DOI: $10.1177 / 1754073915590620$

Schwarz, N., \& Clore, G. L. (1983). Mood, misattribution, and judgments of well-being: Informative and directive functions of affective states. Journal of Personality and Social Psychology, 45, 513-523.

Seeman, T. E., Lusignolo, T. M., Albert, M., \& Berkman, L. (2001). Social relationships, social support, and patterns of cognitive aging in healthy, high-functioning older adults: MacArthur studies of successful aging. Health Psychology, 20, 243-255.

Shaver, P. R., \& Mikulincer, M. (2002). Attachment-related psychodynamics. Attachment \& Human Development, 4, 133-161.

Shiffman, S., Stone, A. A., \& Hufford, M. R. (2008). Ecological momentary assessment. Annual Review Clininical Psychol., 4, 1-32.

Simons, D. J., \& Chabris, C. F. (1999). Gorillas in our midst: Sustained inattentional blindness for dynamic events. Perception, 28, 1059-1074.

Skoyen, J. A., Blank, E., Corkery, S. A., \& Butler, E. A. (2013). The interplay of partner influence and individual values predicts daily fluctuations in eating and physical activity. Journal of Social and Personal Relationships, 30, 1000-1019.

Skoyen, J. A., Kogan, A. V., Novak, S. A., \& Butler, E. A. (2012). Health behavior and emotion regulation in couples. In Newman, M. L., \& Roberts, N. A. (Eds.) Health and social 
Relationships, Affect and Health 52

relationships: The good, the bad, and the complicated (pp. 121-142). Washington, DC: American Psychological Association.

Slatcher, R. B. (2010). Marital functioning and physical health: Implications for social and personality psychology. Social and Personality Psychology Compass, 4, 455-469.

Slatcher, R. B. (2016). Protective processes underlying the links between marital quality and physical health. Current Opinion in Psychology. Available online 28 September 2016

Slavich, G. M., \& Cole, S. W. (2013). The emerging field of human social genomics. Clinical Psychological Science, 1(3), 331-348.

Smith, T., Baron, C., \& Caska, C. (2014). On marriage and the heart: Models, methods, and mechanisms in the study of close relationships and cardiovascular disease. In C. R. Agnew \& S. C. South (Eds.), Interpersonal relationships and health: Social and clinical psychological mechanisms. (pp. 34-70). New York: Oxford University Press.

Smith, T. W., Glazer, K., Ruiz, J. M., \& Gallo, L. C. (2004). Hostility, anger, aggressiveness, and coronary heart disease: An interpersonal perspective on personality, emotion, and health. Journal of Personality, 72, 1217-1270.

Smith, T. W., Uchino, B. N., Florsheim, P., Berg, C. A., Butner, J., Hawkins, M., ... Hopkins, P. N. (2011). Affiliation and control during marital disagreement, history of Divorce, and asymptomatic coronary artery calcification in older couples. Psychosomatic Medicine, 73, 350-357.

Steptoe, A., Demakakos, P., de Oliveira, C., \& Wardle, J. (2012). Distinctive biological correlates of positive psychological well-being in older men and women. Psychosomatic Medicine, 74, 501-508. 
Steptoe, A., O'Donnell, K., Marmot, M., \& Wardle, J. (2008). Positive affect, psychological well-being, and good sleep. Journal of Psychosomatic Research, 64, 409-415.

Steptoe, A., Shankar, A., Demakakos, P., \& Wardle, J. (2013). Social isolation, loneliness, and all-cause mortality in older men and women. Proceedings of the National Academy of Sciences, 110, 5797-5801.

Stroebe, M., Schut, H., \& Stroebe, W. (2007). Health outcomes of bereavement. The Lancet, 370, 1960-1973.

Suomi, S. J. (1999). The emotional dynamics of disruptions in attachment relationships: Implications for theory, research, and clinical intervention. In J. Cassidy \& P. R. Shaver (Eds.), Handbook of attachment: Theory, research, and clinical applications. (pp. 21-43). New York: The Guilford Press.

Suls, J. (in press). Toxic affect-- are anger, anxiety and depression independent risk factors for cardiovascular disease. Emotion Review.

Taylor-Covill, G. A., \& Eves, F. F. (2015). Carrying a biological “backpack”: Quasiexperimental effects of weight status and body fat change on perceived steepness. Journal of Experimental Psychology: Human Perception and Performance. Online First Publication, September 28, 2015. http://dx.doi.org/10.1037/xhp0000137.

Tomaka, J., Blascovich, J., Kelsey, R. M., \& Leitten, C. L. (1993). Subjective, physiological, and behavioral effects of threat and challenge appraisal. Journal of Personality \& Social Psychology, 65, 248-260.

Tomasello, M., Carpenter, M., Call, J., Behne, T., \& Moll, H. (2005). Understanding and sharing intentions: The origins of cultural cognition. Behavioral and Brain Sciences, $28,675-691$. 
Tomasello, M., Carpenter, M., \& Liszkowski, U. (2007). A new look at infant pointing. Child Development, 78, 705-722.

Tucker, J. S. (2002). Health-related social control within older adults' relationships. The Journals of Gerontology Series B: Psychological Sciences and Social Sciences, 57, P387P395.

Tucker, J. S., Klein, D. J., \& Elliott, M. N. (2004). Social control of health behaviors: A comparison of young, middle-aged, and older adults. The Journals of Gerontology Series B: Psychological Sciences and Social Sciences, 59, P147-P150.

Uchino, B. N. (2004). Social support and physical health: Understanding the health consequences of relationships. New Haven, CT: Yale Univ Press.

Uchino, B. N. (2006). Social support and health: A review of physiological processes potentially underlying links to disease outcomes. Journal of Behavioral Medicine, 29, 377-387.

Uchino, B. N., Smith, T. W., \& Berg, C. A. (2014). Spousal relationship quality and cardiovascular risk dyadic perceptions of relationship ambivalence are associated with coronary-artery calcification. Psychological Science, 25, 1037-1042.

Umberson, D. (1987). Family status and health behaviors: Social control as a dimension of social integration. Journal of Health and Social Behavior, 28, 306-319.

Umberson, D. (1992). Gender, marital status and the social control of health behavior. Social Science \& Medicine, 34, 907-917.

Umberson, D., Crosnoe, R., \& Reczek, C. (2010). Social relationships and health behavior across life course. Annual Review of Sociology, 36, 139-157. 
Walton, G. M., \& Cohen, G. L. (2011). A brief social-belonging intervention improves academic and health outcomes of minority students. Science, 331, 1447-1451.

Warneken, F., \& Tomasello, M. (2009). Varieties of altruism in children and chimpanzees. Trends in Cognitive Sciences, 13, 397-402.

Wegner, D. M., Erber, R., \& Raymond, P. (1991). Transactive memory in close relationships. Journal of Personality and Social Psychology, 61, 923-929.

White, E., Shockley, K., \& Riley, M. A. (2013). Multimodally specified energy expenditure and action-based distance judgments. Psychonomic Bulletin \& Review, 20, 13711377.

Woolley, A. W., Chabris, C. F., Pentland, A., Hashmi, N., \& Malone, T. W. (2010). Evidence for a collective intelligence factor in the performance of human groups. Science, 330, 686-688.

Zadra, J. R., \& Clore, G. L. (2011). Emotion and perception: The role of affective information. Wiley Interdisciplinary Reviews: Cognitive Science, 2, 676-685.

Zadra, J. R., Weltman, A. L., \& Proffitt, D. R. (2015). Walkable distances are bioenergetically scaled. Journal of Experimental Psychology: Human Perception and Performance. Advance, Advance online publication. http://dx.doi.org/10.1037/xhp0000107. Zeifman, D., \& Hazan, C. (1997). A process model of adult attachment formation. In S. Duck (Ed.), Handbook of personal relationships (pp. 179-195). Chichester, UK: Wiley and Sons.

Zunzunegui, M.-V., Alvarado, B. E., Del Ser, T., \& Otero, A. (2003). Social networks, social integration, and social engagement determine cognitive decline in community- 
dwelling Spanish older adults. The Journals of Gerontology Series B: Psychological Sciences and Social Sciences, 58, S93-S100. 


\begin{tabular}{|c|c|c|c|c|}
\hline Theory or Model & $\begin{array}{l}\text { Embodied } \\
\text { Information } \\
\text { Processing }\end{array}$ & $\begin{array}{l}\text { Appraisal } \\
\text { Processes }\end{array}$ & $\begin{array}{l}\text { Contingent } \\
\text { Interaction }\end{array}$ & $\begin{array}{l}\text { Transactional } \\
\text { Perspectives }\end{array}$ \\
\hline $\begin{array}{l}\text { Social Baseline (Beckes \& Coan, 2011; Coan \& Sbarra, } \\
\text { 2015) }\end{array}$ & & & & \\
\hline $\begin{array}{l}\text { Attachment Theory - Normative and Coregulatory (Hofer, } \\
\text { 1984; Sbarra \& Hazan, 2008) }\end{array}$ & & & & \\
\hline $\begin{array}{l}\text { Attachment Theory - } \\
\text { Individual Differences (Mikulincer \& Shaver, 2007) }\end{array}$ & & & & \\
\hline $\begin{array}{l}\text { Evolutionary Model of Loneliness (Cacioppo \& Patrick, } \\
\text { 2008) }\end{array}$ & & & & \\
\hline Social Evaluative Threat (Dickerson \& Kemeny, 2004) & & & & \\
\hline $\begin{array}{l}\text { Social Support- Stress Buffering and Main Effects (Cohen } \\
\text { \& Willis, 1985; Uchino, 2004) }\end{array}$ & & & & \\
\hline $\begin{array}{l}\text { Interpersonal Circumplex Models (Kiesler, 1996; Pincus \& } \\
\text { Ansell, 2003; Smith, Gallo, \& Ruiz, 2003) }\end{array}$ & & & & \\
\hline Temporal Interpersonal Emotional Systems (Butler, 2011) & & & & \\
\hline Social Control of Health Behaviors (Umberson, 1997) & & & & \\
\hline
\end{tabular}

Table 1. The rows in the table represent individual theories or models that outline a specific perspective on the ways in which relationships may impact health. The columns represent cross-cutting components that help explain the ways in which social resources (or, lack of social resources) shape affective responses. A check within a cell indicates that a given theory or model emphasizes the specific component. 


\section{Figure Captions}

Figure 1. A simple mediational model in which social resources influence health and alter health-relevant physiology through affective responses. A key goal for this paper is to enumerate the psychological and behavioral processes that constitute the "a path" linking social resources and affective response in this model.

Figure 2. A multiple mediator model connecting social resources to affective responses via four pathways: embodied information processing; appraisal processes; contingent interactions; and, transactional perspectives. These components, drawn from nine different relationship theories, illustrate the affective mechanisms through which social resources may ultimately influence health outcomes. 


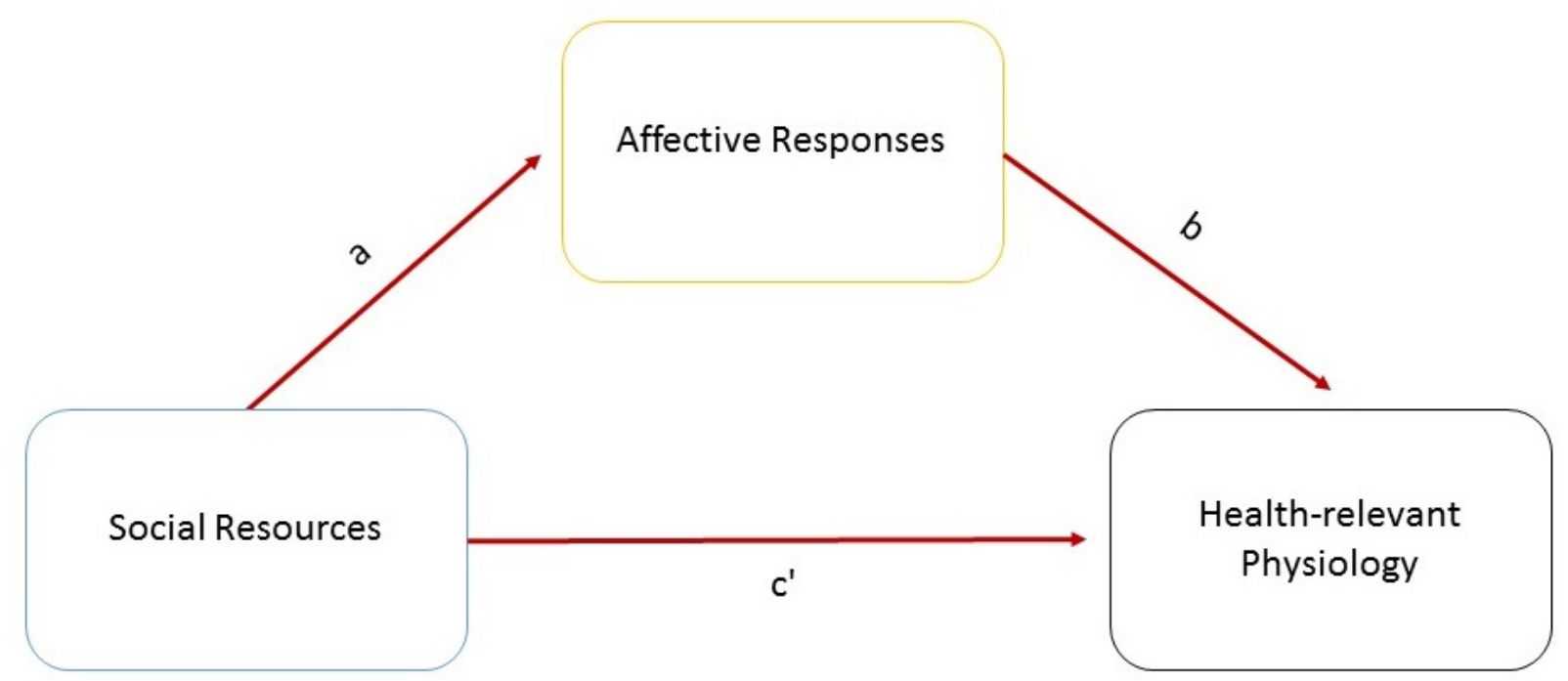




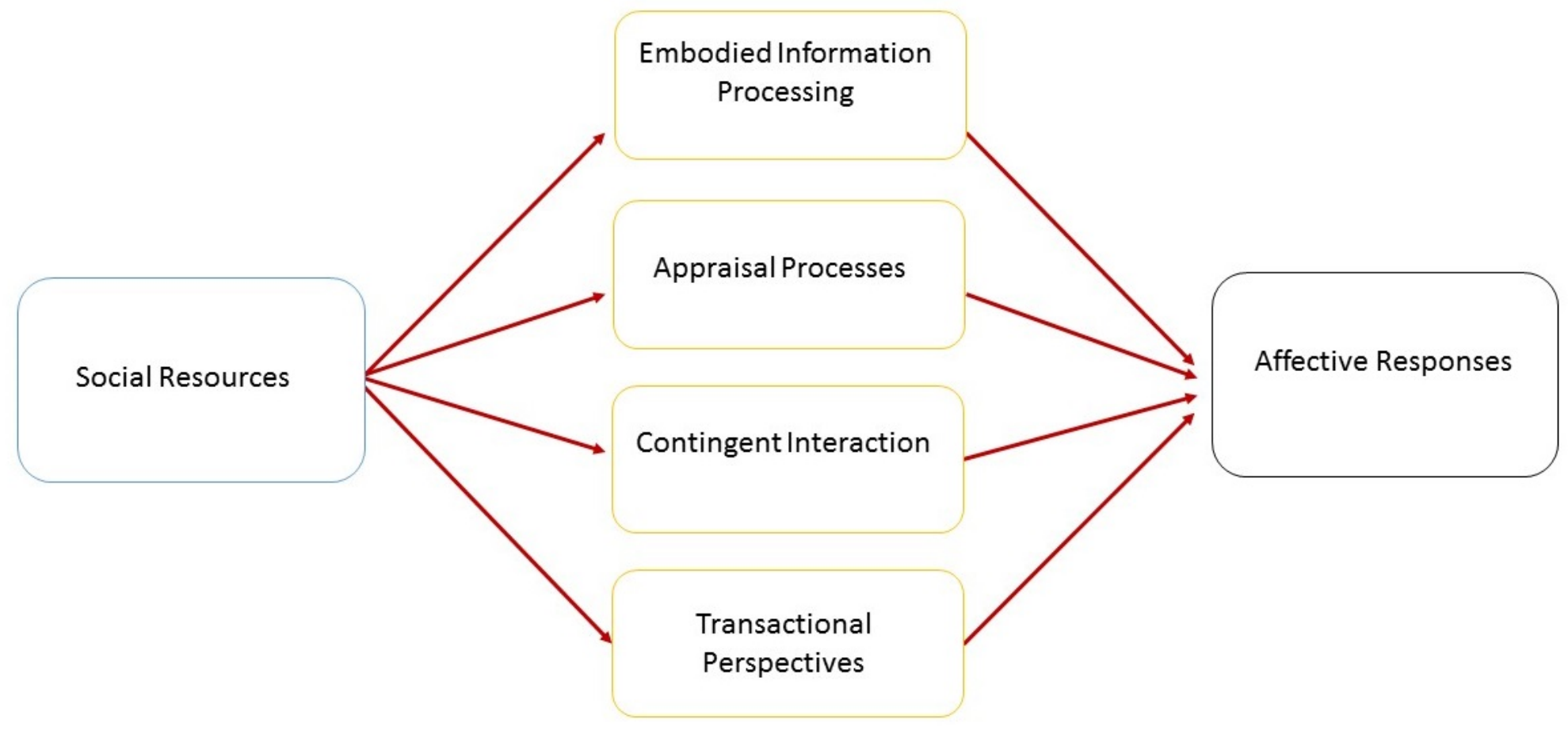

